\title{
Analisis Prosodi pada Monolog Aktor Film Menggunakan Aplikasi Praat (Kajian dalam Bidang Fonetik Akustik)
}

\author{
Tri Wahyu Retno Ningsih \\ Fakultas Sastra dan Budaya, Universitas Gunadarma \\ twahyurn@gmail.com
}

\begin{abstract}
The aims of study is identifying speaker voices base on acoustic parameters extracted from fundamental frequency (F0), duration, intensity, stress, and contour in the speech sounds. In the present experiment of speaker voice, the parameters of the signal have been extracted by means of a spectrum analyzer with the help computer. The recordings were saved in WAV files, and Praat software version 6.0.14 (Boersma \& Weenink, 2016) was used to analyze the suprasegmental features. Praat is a computer program for analysing, synthesizing, and manipulating speech. The method of the research is experimental method. Experiment related to the speaker identification and verification have been conducted using acoustic parameters of speaker obtained from the spectrographic analysis. To study whether objective acoustic analysis is able to differentiate between natural and manipulation voices. The results indicate that the acoustic parameters of fundamental frequency (F0), duration, intensity, stress, and contour of the speech sounds can be used for differentiate between natural and manipulation voices.
\end{abstract}

Keywords: Acoustics phonetics; experimental; suprasegmental; monolog; Praat software.

\section{Intisari}

Tujuan penelitian ini adalah mengidentifikasi bunyi ujaran penutur mengunakan parameter akustik, seperti frekuensi fundamental (F0), durasi, intensitas, tekanan dan pola kontur. Pengukuran bunyi ujaran ekperimental ini menggunakan sinyal yang diekstrak menggunakan anlisis spektrum dengan bantuan komputer. Hasil rekaman suara disimpan dalam file WAV dan software Praat versi 6.0.14 (Boersma \& Weenink, 2016) digunakan untuk menganalisis fitur-fitur suprasegmental tersebut. Praat adalah program komputer untuk menganalisis, sintesis, dan manipulasi bunyi ujaran. Metode penelitian adalah metode eksperimental. Eksperimen terkait dengan identifikasi dan verifikasi bunyi ujaran penutur menggunakan parameter akustik melalui analisis spektograf. Kajian fonetik akustik ini dapat digunakan untuk membedakan antara bunyi asli atau bunyi tiruan oleh penutur. Hasil penelitian mengindikasikan bahwa parameter akustik seperti frekuensi fundamental (F0), durasi, intensitas, tekanan dan pola kontur dapat digunakan untuk membedakan bunyi ujaran asli dan bunyi ujaran tiruan penutur

Kata kunci: Fonetik akustik; eksperimental; suprasegmental; monolog; software Praat. 


\section{Pendahuluan}

Kajian bidang fonetik dan fonologi merupakan bidang linguistik yang sangat menarik dan saling terkait. Kajian ini didasarkan pada pengukuran sistem ujaran manusia, persepsi ucapan, intuisi penutur, dan sistem bahasa berupa vokal dan konsonan. Kajian akustik ini membahas tentang pola-pola tekanan, realisasi akustik, dan penilaian perseptual tentang batas silabel, kata, frasa, dan kalimat yang diproduksi oleh penutur. Kajian mengenai bunyi ujaran atau bunyi bahasa ini menjelaskan bagaimana bunyi-bunyi tersebut dibuat secara akustik (Pickett, 1999). Akustik meneliti sifat-sifat fisik bunyi ujaran dengan mengacu pada realisasi akustik linguistik terkait bunyi ujaran.

Dalam era modern saat ini, para ilmuwan dalam bidang fonetik mencari pendekatan ilmiah yang objektif, misalnya kajian eksperimental dan instrumental yang mencakup penelitian akustik pada sistem ujaran suatu bahasa. Kajian akustik menyediakan metode ilmiah untuk melakukan analisis objektif ujaran dengan mengukur sifat fisik ujaran dan realisasi akustiknya. Pengukuran sifat ujaran dilakukan dengan menghitung fitur-fitur suprasegmental, durasi, dan intensitas, yang digunakan untuk menganalisis pola ujaran suatu bahasa.

Kajian fonetik dan fonologi dilakukan di banyak bahasa, seperti bahasa Inggris, bahasa Belanda, bahasa Perancis, bahasa Jerman, bahasa Indonesia, dan bahasa di Nusantara (Ningsih, 207). Dari berbagai penelitian tersebut, masing-masing bahasa memiliki inventaris fonemiknya sendiri, tata bunyi, dan aturan fonologis dan fonetik yang berbeda dari bahasa lain, bahkan sebagian besar bahasa memiliki sistem ortografi yang berbeda. Fry (1955, 1958) adalah tokoh akustik dalam bahasa Inggris yang menerapkan faktor-faktor akustik, seperti durasi, intensitas, dan frekuensi fundamental (F0) untuk mengukur bunyi ujaran pada penutur bahasa Inggris. Salah satu peneliti akustik lainnya, yaitu Gordon (2004) juga meneliti penggunaan tekanan dalam tuturan menggunakan parameter akustik, durasi, frekuensi dasar, intensitas, dan kualitas vokal untuk menentukan tingkat leksikal, tekanan primer, sekunder, dan secara fonetis pada 8 penutur Chickasaw.

Hasil penelitian Gordon (2004) menunjukkan terdapat banyak aspek yang memengaruhi analisis fonologis dari tekanan dalam suatu bahasa, misalnya, aspek intonasi 
penutur dalam ujaran, struktur silabel, dan morfologi. Oleh karena itu, analisis akustik terbukti dapat digunakan untuk mengukur fitur-fitur akustik, seperti tekanan, durasi, F0, intonasi, nilai forman, dan fitur-fitur akustik lainnya sesuai dengan kebutuhan penelitian. Penelitian ini mencakup semua aspek penelitian fonetik eksperimental menggunakan Praat (Boersma \& Weenink, 2014) untuk memeriksa 2000 sampel suara monolog aktor film dengan berbagai karakter tokoh dalam film-film yang pernah dibintanginya.

Berdasarkan penelitian Boersma \& Weenink (2014), penelitian ini bertujuan untuk menemukan fitur-fitur akustik pembeda yang ditemukan dalam monolog aktor film. Penelitian ini dilatari oleh wawancara Sarah Sechan dengan Reza Rahadian dalam salah satu acara talk show di NET TV. Dalam acara tersebut, Reza diminta untuk membacakan skenario film berdasarkan karakter tokoh pada film yang pernah dibintangi Reza. Data sumber adalah ujaran yang diproduksi oleh salah satu aktor film Indonesia, yaitu Reza Rahadian dalam karakter tokoh yang berbeda-beda dalam film. Data ujaran tersebut digunakan sebagai sampel ujaran yang dianalisis. Sampel ujaran direkam dan disimpan dalam bentuk wav untuk diukur fitur-fitur akustiknya, seperti frekuensi fundamental, tekanan, durasi, dan intonasi. Pengukuran tersebut bertujuan untuk menemukan fitur-fitur akustik pembeda antara bunyi asli dan bunyi tiruan pada sampel ujaran.

Fonetik adalah kajian ilmiah yang meneliti bagaimana manusia menghasilkan bunyi ujaran dan gelombang bunyi, serta bagaimana alat bantu dengar manusia dapat menerima bunyi ujaranyang akan dianalisis oleh otak manusia. Berdasarkan komponennya, fonetik akustik memiliki 3 karakteristik yaitu frekuensi, durasi, dan intensitas. Meskipun banyak karakteristik lain yang dapat diukur, seperti tekanan, jitter, shimmer, pitch range, tempo, forman (F1 dan F2), dan sebagainya tergantung dari kebutuhan peneliti.

Prosodi dikaji dalam bidang fonetik akustik. Prosodi adalah fitur-fitur suprasegmental yang kaya akan informasi dalam bahasa lisan. Istilah yang sering digunakan untuk menggambarkan informasi prosodi adalah nada, tekanan intonasi, ritme, dan durasi. Prosodi menandai banyak hal, seperti menggambarkan emosi penutur, mempunyai kekuatan pragmatis di balik ujaran, dan sekaligus memuat informasi demografis dan budaya tentang penutur. Bagi kebanyakan linguis fenomena ini menarik untuk diteliti karena prosodi dapat mengkomunikasikan makna, baik dalam bentuk ujaran maupun bagaimana kita mengujarkannya. Konstituen prosodi lain yang tampaknya diterima secara luas adalah frasa 
intonasi. Ungkapan intonasi merupakan sekelompok kata dalam ujaran, yang dibatasi dalam beberapa cara sebagai unit ungkapan yang lebih besar. Ladd (1986) melacak asal-usul frasa intonasi dan Ladd mengidentifikasi tiga sifat umum, yaitu entitas fonologis mempuyai batas-batas yang dapat didefinisikan secara fonetik sehingga ujaran dapat disegmentasikan dan memiliki struktur intonasi tertentu.

Komponen prosodi merupakan realisasi perseptual dan akustik pada tingkat suprasegmental (Lehiste, 1970). Variasi dalam prosodi memiliki berbagai fungsi ekspresif dalam domain semantik, sikap, psikologis, dan sosial (Crystal, 2008). Pentingnya aspek prosodi yang paling nyata adalah fungsi linguistiknya, seperti nada leksikal, tekanan kontras, dan pola kontur. Dalam bahasa tonal, variasi nada leksikal menyampaikan makna pada tingkat suku kata. Misalnya, dalam bahasa Mandarin Cina, ketika suku kata 'ma' diproduksi dengan nada (tone) tingkat tinggi dan rendah mempunyai makna yang berbeda. Dalam bahasa nontonal, seperti bahasa Inggris, variasi dalam prosodi dapat menyebabkan perubahan makna linguistik pada tingkat kata, frasa, dan kalimat. Parameter akustik terdiri atas F0, intensitas, dan pola durasi (Hadding-Koch \& Studdert-Kennedy, 1964; StuddertKennedy \& Hadding, 1973).

Variasi dalam frekuensi fundamental (F0) merupakan korelasi akustik utama dari perubahan nada ujaran. Variasi dalam kontur F0 dapat menyebabkan perubahan dalam pola prosodi pada berbagai tingkat unit linguistik (misalnya kata, frasa, kalimat, dan wacana). Sebagai contoh, pada tingkat kalimat, ujaran interogatif dapat dibedakan dari bentuk deklaratifnya dengan membuat variasi pada pola F0-nya. Kalimat deklaratif ditandai dengan kontur F0 'nada menurun') pada akhir ujaran, sedangkan kontur F0 dalam ujaran interogatif umumnya, ditandai dengan 'nada naik' (rising intonation), meskipun ada sebagian kontur F0 yang mempunyai pola kontur turun (Ladefoged, 2001). Demikian pula, ujaran yang belum selesai dapat memiliki pola variasi F0 yang berbeda. Silabel terakhir dalam ujaran tersebut cenderung memiliki puncak F0 yang lebih tinggi, pola kontur turun F0 lebih rendah (Berkovits, 1984). Kontur F0 dalam intonasi dapat menandai ujaran deklaratif atau interogatif (Ladd, 1996; Lehiste, 1970, 1976), perubahan pada kontur F0 sering terjadi bersamaan dengan variasi intensitas dan pola durasi (Freeman, 1982). Penelitian sebelumnya juga menunjukkan bahwa sifat akustik F0, intensitas, dan pola durasi semua dapat berkontribusi pada persepsi kontras intonasi ucapan pada pendengar dengan pendengaran normal (NH; Fry, 1955, 1958; Lehiste, 1970, 1976; Lieberman, 1967 ). 
Penentuan fitur-fitur akustik yang digunakan dalam pengukuran akustik, seperti tekanan dilatar belakangi oleh berbagai literatur dalam bidang fonetik akustik, yang menyatakan bahwa tekanan kata dalam sebuah kalimat mempunyai makna leksikal tertentu. Pengukuran tekanan pada silabel dilakukan dengan mengukur panjang atau durasi vokal, kualitas vokal, kenyaringan, dan nada ujaran. Ciri-ciri pengukuran akustik pada silabel yang mendapat tekanan adalah mempunyai durasi lebih panjang (lama), lebih nyaring dibandingkan dengan silabel yang letaknya berdampingan, atau dapat juga ditandai dengan gerakan pitch. Gordon (2004) menjelaskan bahwa, pada tingkat suprasegmental, tekanan sering menyebabkan pemanjangan (durasi), F0 lebih tinggi, dan intensitas lebih tinggi.

Alat yang digunakan untuk mengukur gelombang bunyi ujaran dan pergerakan bunyi adalah spektrograf (alat untuk menganalisis frekuensi dan tekanan), dan osiloskop (alat untuk menggambarkan karakteristik kenyaringan suara). Spektograf digunakan untuk menunjukkan frekuensi yang dikontraskan dengan tempo dan durasi. Gambar 2.1 adalah contoh gelombang suara dalam spektograf:

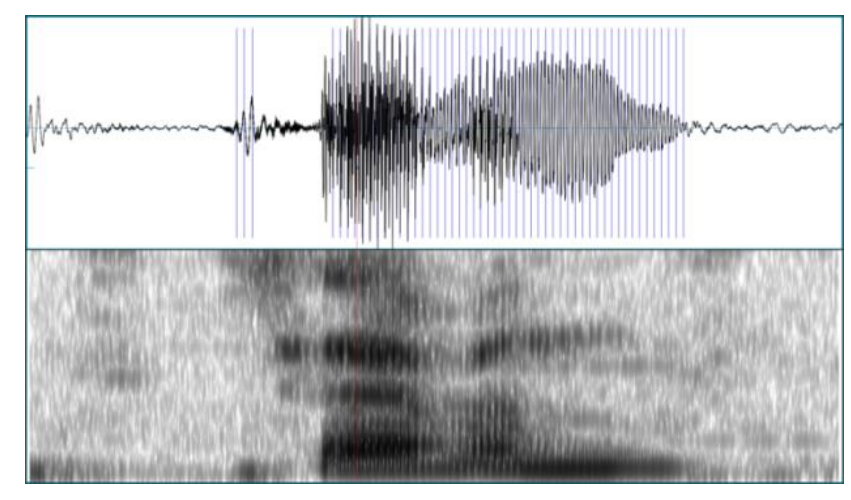

Gambar 2.1. Contoh spektogram

Spektrogram adalah gambar atau diagram yang dihasilkan oleh spektograf. Spektogram adalah grafik bunyi yang memberikan informasi tentang perubahan dalam rentang waktu, frekuensi, dan intensitas gelombang bunyi menurut sumbu waktu. Melalui analisis spektrogram, dapat dilihat bahwa frekuensi berubah sebagai fungsi waktu dan komponen frekuensi dalam suatu sinyal dapat diukur.

Dalam berbagai penelitian disebutkan bahwa masing-masing bahasa mempunyai perbedaan tekanan dan bukan tekanan, seperti perbedaan antara tingkat tekanan primer, sekunder, dan tersier (De Lacy, 2007). Analisis tekanan juga telah dilakukan sejak awal tata 
bahasa generatif (Chomsky, Halle \& Lukoff, 1959). Beberapa peneliti mengenai tekanan dalam berbagai bahasa adalah Beckman (1986); Fry (955) dalam bahasa Inggris, bahasa Indonesia (Adisasmito-Smith \& Cohn, 1996), bahasa Belanda (Sluijter \& Heuven, 1996).

Tekanan dapat digunakan untuk memverifikasi pola F0 kata karena dalam kata tersebut terdapat nada tinggi atau rendah sehingga ditemukan tekanan dalam kata tersebut. Gordon (2011) berpendapat bahwa silabel yang mendapat tekanan atau silabel yang tidak memiliki tekanan dikaitkan dengan aspek suprasegmental dan segmental. Tekanan biasanya mengaktifkan pemanjangan durasi, F0 yang lebih tinggi, dan intensitas yang lebih besar. Crystal (2008) mendefinisikan istilah tekanan sebagai tingkat energi yang digunakan dalam memproduksi silabel. Analisis tekanan pada silabel didasarkan pada faktor kenyaringan silabel ditambah dengan durasi. Peran kunci dari tekanan dalam fonologi adalah untuk membedakan antara penekanan dan kontras tekanan. Masing-masing bahasa mempunyai tekanan yang berbeda-beda pada berbagai posisi kata, yang menjelaskan kenyaringan, pitch, dan durasi. Perubahan nada tersebut bersama dengan aspek lain tersebut disebut sebagai tekanan (Harrington \& Cox, 1984b).

\section{Metode Penelitian}

Metode penelitian yang digunakan adalah metode eksperimental, yaitu mengukur sinyal ujaran menggunakan program komputer Praat (Boersma \& Weenink, 2016). Pengumpulan data dilakukan melalui proses perekaman acara ‘talk show' yang dipandu oleh Sarah Sechan dari acara Net TV yang diakses melalui youtube.com (https://www.youtube.com/watch?v=6M-lyY4xW7c). Dalam acara talk show tersebut, Sarah Sechan meminta Reza Rahadian untuk membaca script atau skenario film sesuai dengan karakter yang pernah dimainkan oleh Reza Rahadian dalam film yang berbeda-beda, seperti film 3 Hati, 2 Dunia, 1 Cinta Perempuan Berkalung Sorban, Emak Ingin Naik Haji, Tenggelamnya Kapal Van der Wijck, My Stupid Boss, Habibie \& Ainun, dan Battle of Surabaya. ta ujaran yang terkumpul sebanyak 6 sampel data ujaran, yaitu 1 data ujaran asli dan 5 data ujaran tiruan sebagai pembanding. Data ujaran asli adalah sampel suara aktor film yang asli tanpa ada perubahan karakter, sementara itu, data ujaran tiruan adalah sampel ujaran yang diujarkan sesuai dengan karakter tokoh film yang pernah dimainkan oleh Reza Rahadian. Dalam penelitian ini, tidak semua data ujaran sumber dianalisis karena syarat sampel data yang dapat dianalisis adalah data yang jernih dan tidak mengandung noise 
sehingga hanya data yang memenuhi syarat tersebut yang dapat dianalisis. Semua data tersebut direkam dan diolah menggunakan software Praat.

Proses pengambilan data sampai dengan analisis data menggunakan program komputer Praat. Gambar 3.1 adalah blok diagram alur yang menjelaskan proses analisis sampel data ujaran sampai ditemukan luaran penelitian.

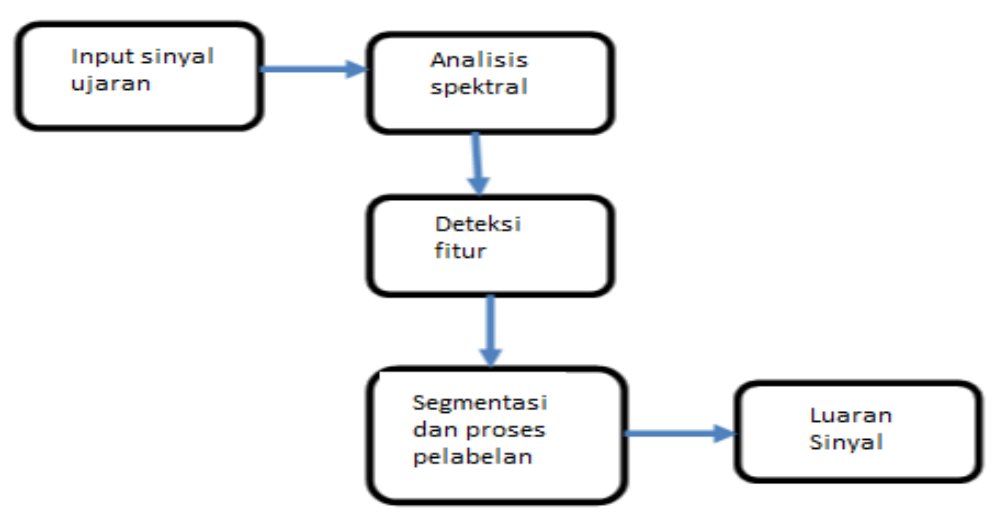

Gambar 3.1. Diagram blok analisis sinyal akustik

Gambar 3.1 menjelaskan tentang langkah-langkah dalam mengananalisis data akustik, yaitu (1) input sinyal ujaran yang bersumber dari data rekaman, (2)analisis spektral (sound waves dan spectrogram) dan (3) mendeteksi fitur-fitur suprasegmental sesuai dengan kebutuhan, (4) segmentasi dan pelabelan ujran, dan luaran sinyal (Hz). Dalam penelitian ini, fitur-fitur suprasegmental yang diukur adalah frekuensi fundamental (F0), durasi, intensitas, tekanan, dan pola kontur. Pengukuran fitur-fitur suprasegmental tersebut untuk menemukan pembeda signifikan antara masing-masing fitur yang diteliti.

\section{Hasil dan Pembahasan}

Hasil analisis akustik pada sampel ujaran asli menggunakan software Praat dijelaskan pada gambar 4.1: 


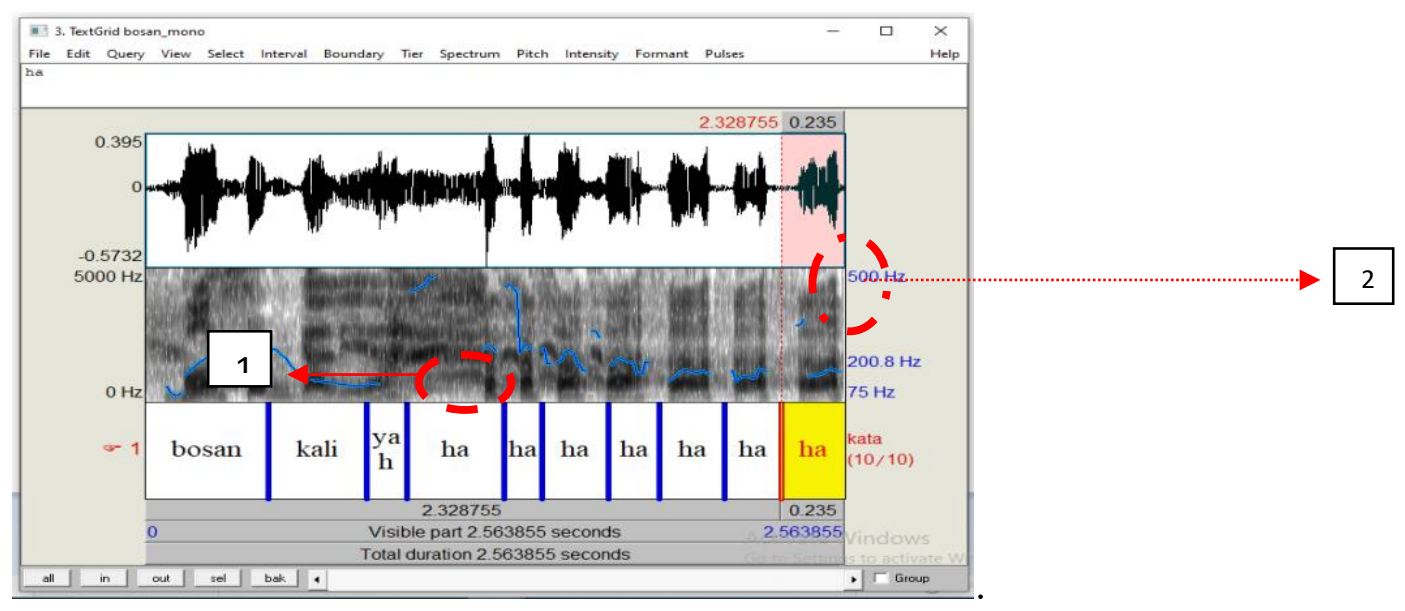

Gambar 4.1 Hasil analisis akustik sampel ujaran asli

Dari sampel tersebut diperoleh nilai mean F0 (211.949 Hz), nilai minimum F0 (96.922 Hz), dan nilai maksimum F0 (469.712 Hz). Pada gambar kode (1) menunjukan nilai F0 minimum dan kode 2 menunjukkan nilai F0 maksimum. Hasil analisis nilai F0 digunakan untuk mengidentifikasi penutur terkait dengan jenis kelamin dan usia penutur. Setelah pengukuran data ujaran asli, maka dilakukan pengukuran untuk data sampel ujaran tiruan atau sampel ujaran manipulasi. Hasil analisisnya dijelaskan pada tabel 4.1:

Tabel 4.1 Perbandingan Hasil Analisis Akustik Data-1 sampai Data-5

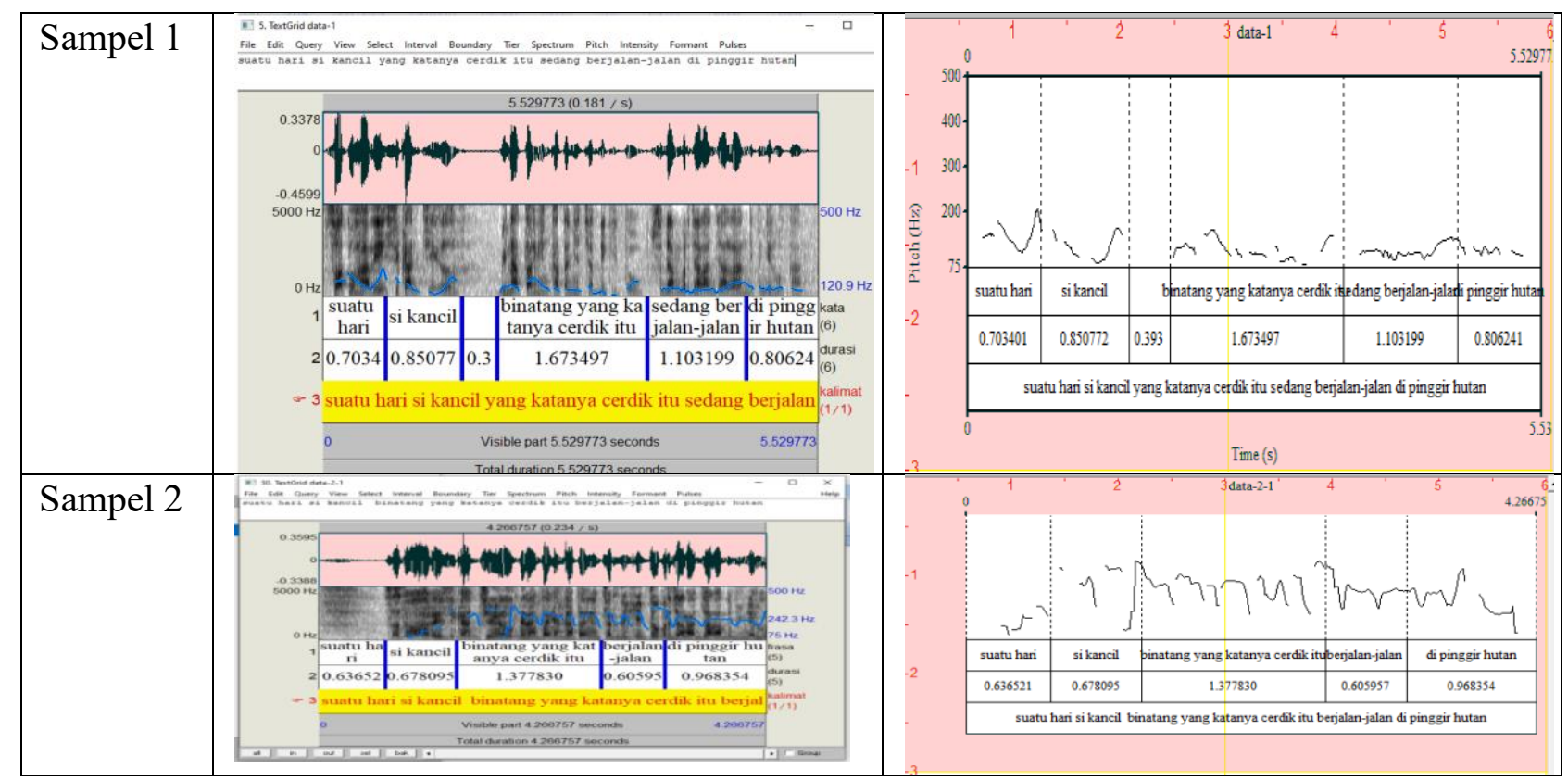


Tri Wahyu Retno N., Analisis Prosodi pada Monolog Aktor Film Menggunakan Aplikasi

Praat (Kajian dalam Bidang Fonetik Akustik)

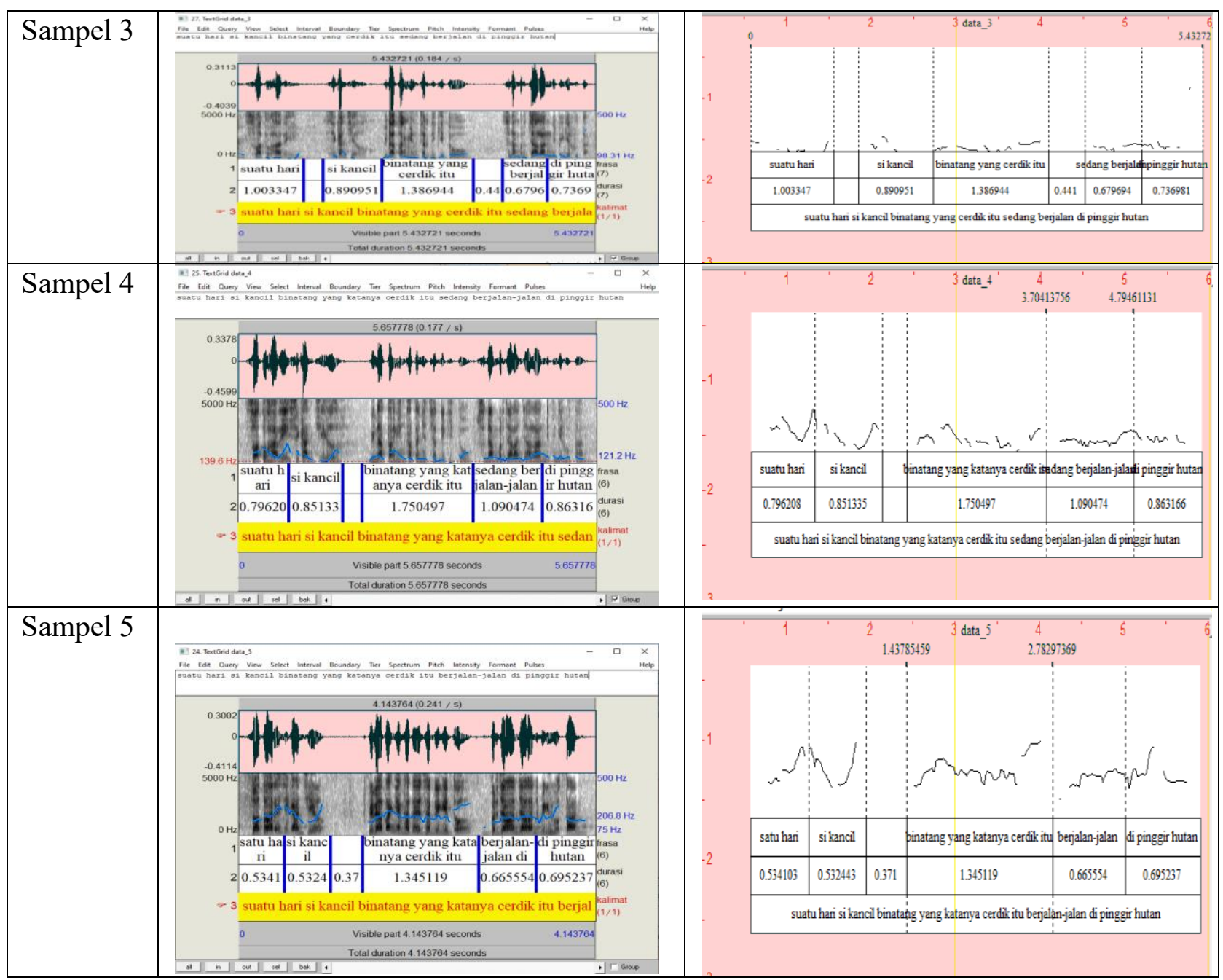

Dari tabel 4. 1 dibuat tabel perbandingan analisis nilai F0, nilai durasi, dan intonasi final.

Tabel 4.2. Nilai Pitch (F0) (Mean, Minimum, Maksimum (Hz)

\begin{tabular}{|l|l|l|}
\hline Sampel 1 & Mean Pitch (F0) & $120.87493571006898 \mathrm{~Hz}$ \\
\cline { 2 - 3 } & Minimum Pitch (F0) & $82.14807859151358 \mathrm{~Hz}$ \\
\cline { 2 - 3 } & Maksimum Pitch (F0) & $205.98579455430522 \mathrm{~Hz}$ \\
\hline Sampel 2 & Mean Pitch (F0) & $242.3294284437203 \mathrm{~Hz}$ \\
\cline { 2 - 3 } & Minimum Pitch (F0) & $91.46442429824687 \mathrm{~Hz}$ \\
\cline { 2 - 3 } & Maksimum Pitch (F0) & $364.6878006941266 \mathrm{~Hz}$ \\
\hline Sampel 3 & Mean Pitch (F0) & $98.3070404451644 \mathrm{~Hz}$ \\
\cline { 2 - 3 } & Minimum Pitch (F0) & $75.05403356600996 \mathrm{~Hz}$ \\
\cline { 2 - 3 } & Maksimum Pitch (F0) & $336.5215427078264 \mathrm{~Hz}$ \\
\hline Sampel 4 & Mean Pitch (F0) & $236.01715152466986 \mathrm{~Hz}$ \\
\cline { 2 - 3 } & Minimum Pitch (F0) & $89.61951579101066 \mathrm{~Hz}$ \\
\cline { 2 - 3 } & Maksimum Pitch (F0) & $365.4365699288945 \mathrm{~Hz}$ \\
\hline Sampel 5 & Mean Pitch (F0) & $206.7783089249922 \mathrm{~Hz}$ \\
\cline { 2 - 3 } & Minimum Pitch (F0) & $130.78721340164046 \mathrm{~Hz}$ \\
\cline { 2 - 3 } & Maksimum Pitch (F0) & $294.437561140041 \mathrm{~Hz}$ \\
\hline
\end{tabular}


Dari sampel tersebut terdapat perbedaan nilai F0 dari sampel-1 sampai dengan sampel -5, dengan perbandingan $(120.874 \mathrm{~Hz}) ;(242.329 \mathrm{~Hz}) ;(98.307 \mathrm{~Hz}),(236.017 \mathrm{~Hz})$; (206.778), sementara sampel ujaran asli adalah 211.949 Hz. Dari ke-5 sampel ujaran tersebut yang mendekati nilai yang hampir sama dengan sampel ujaran asli adalah data ke-5. Sampel ke-5 ini Reza menjadi pengisi suara (dubber) untuk film animasi Battle of Surabaya, seorang pemuda yang bernama Danu, seorang pemuda yang tegas, representasi double agent yang memiliki misinya tersendiri.

Hasil analisis durasi hanya dilakukan untuk mengukur sampel bunyi tiruan 1 sampai dengan 5 karena sampel ujaran asli menggunakan teks yang berbeda. Hasil pengukuran durasi tersebut dijelaskan pada gambar 4.1.

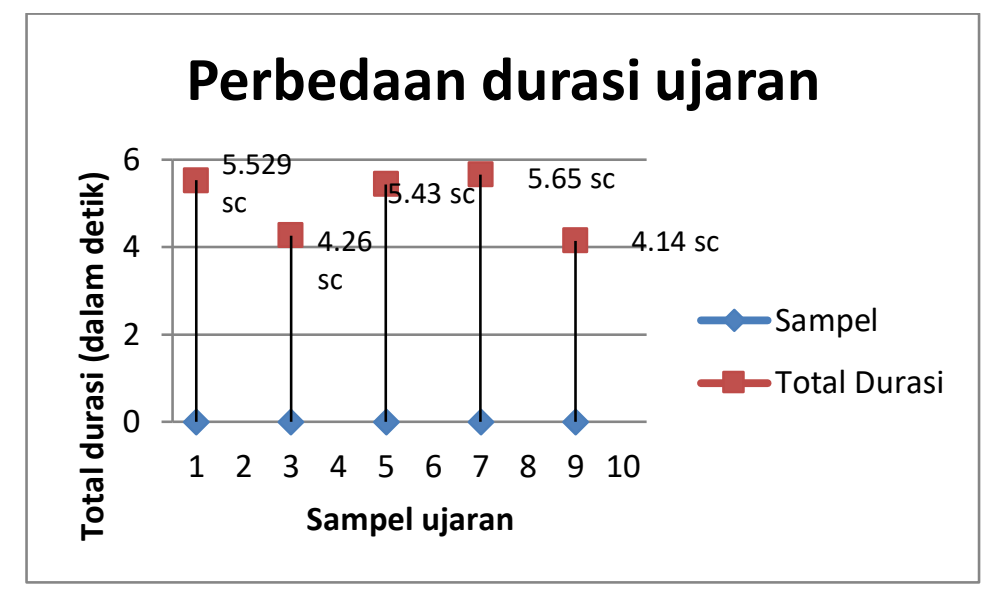

Gambar 4.2 . Perbedaan durasi ujaran (second/detik)

Durasi untuk sampel ujaran asli tidak dibandingkan karena teksnya berbeda. Dari hasil analisis durasi pada sampel ujaran, terdapat dua kelompok yang berbeda, yaitu kelompok sampel 1, 3, dan 4 dan kelompok lainnya adalah sampel 2 dan 5.

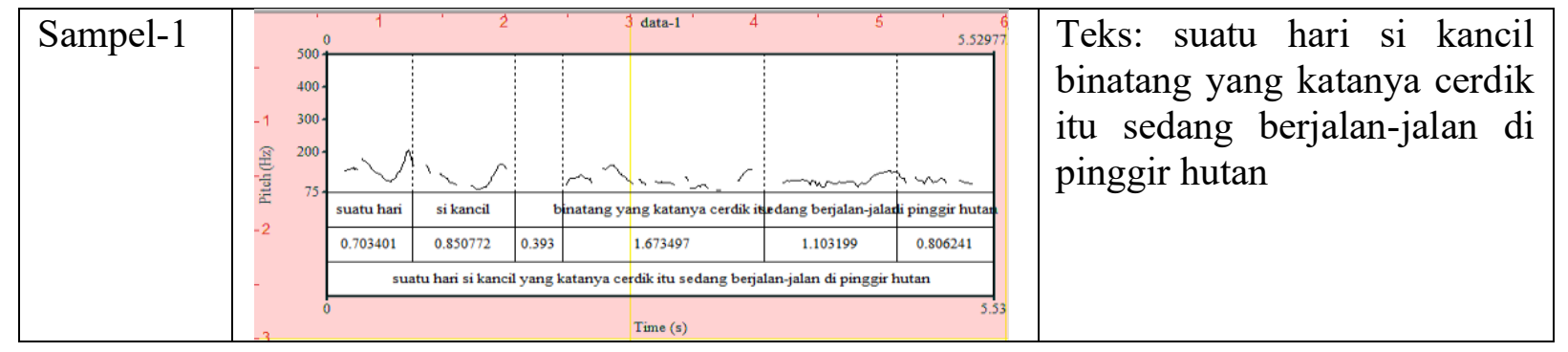




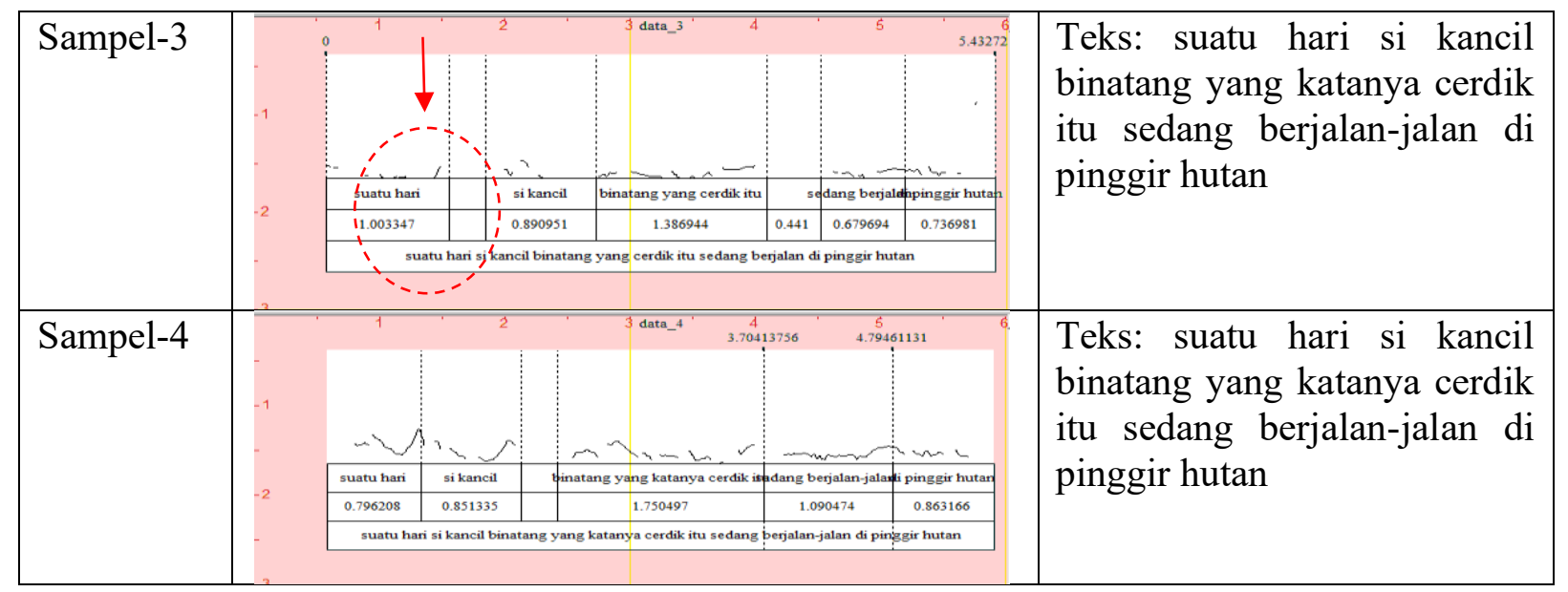

Dari sampel tersebut terlihat ada beberapa kata yang dilesapkan pada sampel 3, yaitu 'suatu hari si kancil binatang yang katanya cerdik itu sedang berjalan-jalan di pinggir hutan'. Meskipun demikian durasi pada sampel ujaran 1, 3, dan 4 mempunyai durasi yang hampir mirip. Perbedaan durasi terlihat pada sampel-3 yang disebabkan oleh nada flat atau datar pada awal kalimat frasa suatu hari yang memerlukan durasi 1.003...detik, sedangkan sampel-1 dan 4 frasa suatu hari dengan durasi (0.70 detik) dan (0.76 detik). Pada sampel-3 juga terlihat masing-masing frasa diujarkan menggunakan jeda (pause) dibandingkan sampel ujaran lainya.

\begin{tabular}{|l|l|l|l|l|l|l|}
\hline Sampel-2 & & Sampel-5 \\
\hline
\end{tabular}

Hasil analisis pada sampel 2 dan 5 menunjukkan bahwa kata 'sedang' tidak digunakan dalam teks tersebut sehingga durasi sampel 2 dan 5 lebih pemdek dibandingkan dengan sampel 1 , 3 , dan 4 .

Pengukuran kenyaringan pada sampel ujaran adalah menghitung nilai desibel (dB). Hasil analisis intensitas dijelaskan pada tabel 4.3. 
Tabel 4.3. Perbandingan hasil analisis intensitas $(\mathrm{dB})$

\begin{tabular}{|l|l|l|l|}
\hline Sampel & Mean intensitas & Minimum intensitas & Maksimum intensitas \\
\hline Sampel-1 & $64.594 \mathrm{~dB}$ & $39.541 \mathrm{~dB}$ & $76.467 \mathrm{~dB}$ \\
\hline Sampel-2 & $68.164 \mathrm{~dB}$ & $42.408 \mathrm{~dB}$ & $75.040 \mathrm{~dB}$ \\
\hline Sampel-3 & $62.558 \mathrm{~dB}$ & $37.677 \mathrm{~dB}$ & $73.654 \mathrm{~dB}$ \\
\hline Sampel-4 & $76.271 \mathrm{~dB}$ & $39.345 \mathrm{~dB}$ & $76.521 \mathrm{~dB}$ \\
\hline Sampel-5 & $67.779 \mathrm{~dB}$ & $35.901 \mathrm{~dB}$ & $76.385 \mathrm{~dB}$ \\
\hline Sampel-asli & $71.209 \mathrm{~dB}$ & $49.260 \mathrm{~dB}$ & $77.927 \mathrm{~dB}$ \\
\hline
\end{tabular}

Hasil analisis intensitas menunjukkan bahwa sampel 4 mendekati tingkat intensitas sampel asli karena 2 sampel ujaran tersebut diujarkan dengan lebih ekspresif, lebih senang, dan berbeda dengan sampel ujaran lain yang diujarkan lebih rendah. Ujaran dari berbagai karakter tokoh menunjukkan perbedaan intensitas terkait dengan karakteristik tokoh. Dari ujaran tersebut terlihat bahwa kata 'kancil' adalah kata yang mendapat tekanan lebih tinggi dibandingkan dengan kata lainnya. Hal ini menunjukkan bahwa 'si kancil' adalah karakter tokoh kuat dalam teks tersebut.

Pengukuran kontur ujaran juga dilakukan untuk melihat intonasi finalnya. Kontur ujaran

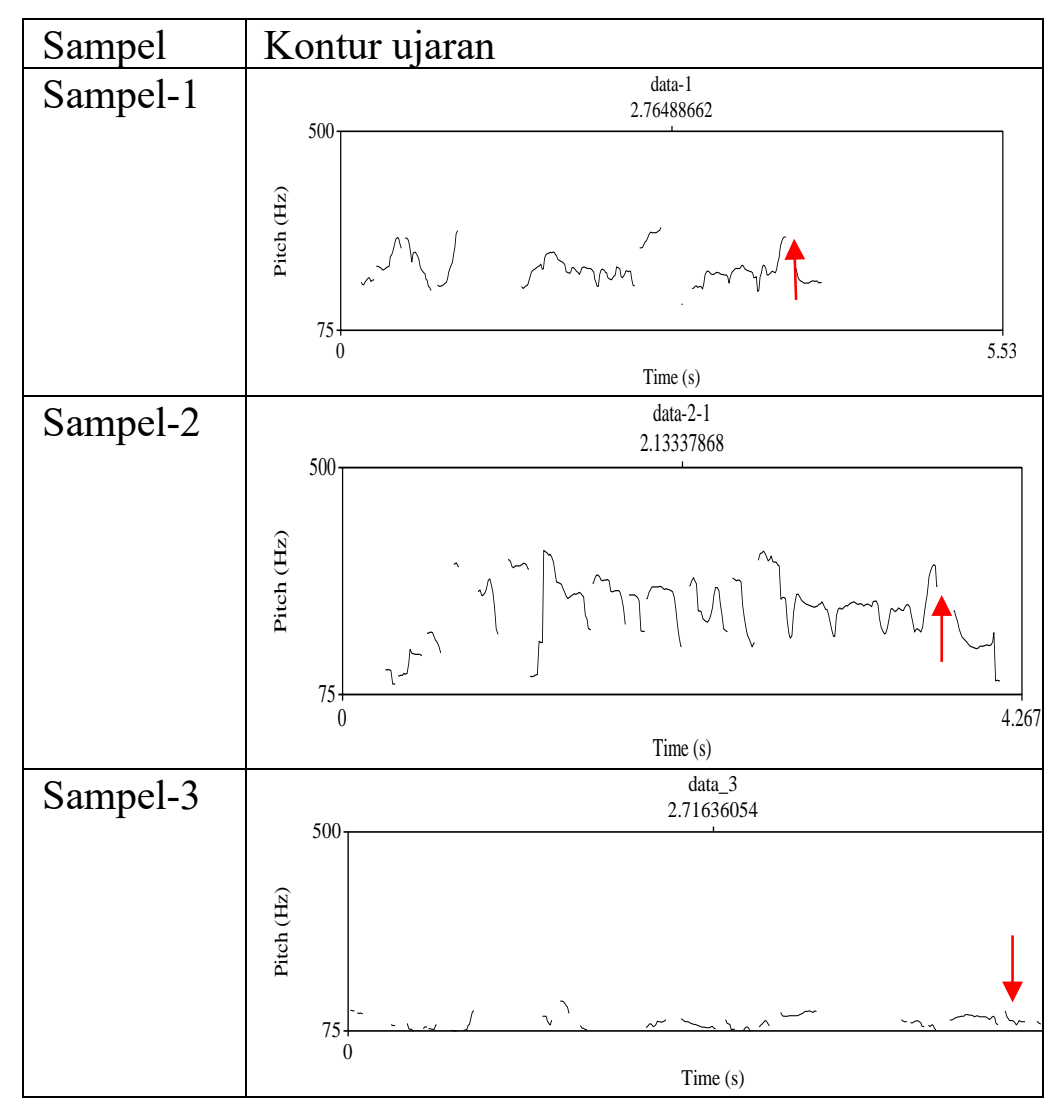




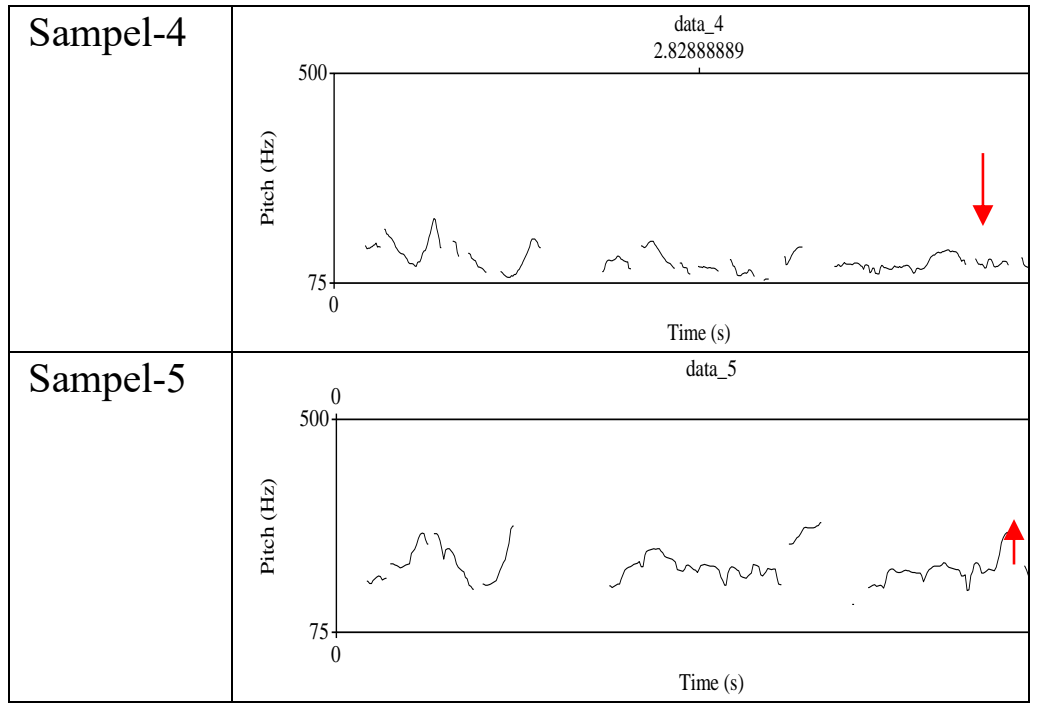

Hasil analisis sampel menunjukkan bahwa sampel 3, dan 4 menunjukkan intonasi final turun, sedangkan sampel 1, 2, dan 5 menunjukkan intonasi final naik yang mengindikasikan bahwa kalimat tersebut belum final diujarkan.

\section{Simpulan}

Hasil penelitian ini membuktikan bahwa terdapat perbedaan nilai akustik pada hasil pengukuran sampel ujaran dari 1 aktor film. Semua fitur-fitur akustik yang diukur, yaitu frekuensi fundamental (F0), durasi, tekanan, intensitas, dan pola kontur menunjukkan nilai yang berbeda. Dari semua fitur tersebut, semua fitur akustik berkontribusi dalam memberikan informasi pembeda antara sampel ujaran asli dan tiruan, serta perbedaan antara fitur akustik dari peran satu tokoh dengan tokoh lainnya dalam film yang diperankan oleh aktor film. Dari hasil analisis tersebut, dapat disimpulkan bahwa nilai F0 menunjukkan, jika sampel ujaran seperti bukan berasal dari satu aktor film, kata 'si kancil' mendapat tekanan pada semua sampel ujaran, beberapa kata dalam teks atau skenario dihilangkan sehingga mempengaruhi total durasi. Pola kontur yang dihasilkan menunjukkan 2 pola, yaitu pola naik dan pola turun. Pola naik pada akhir ujaran menunjukkan bahwa ujaran tersebut belum selesai, sedangkan pola turun pada akhir ujaran menjelaskan bahwa intonasi ujaran tersebut sudah final.

\section{Daftar Pustaka}

Adisasmito-Smith, Niken \& Cohn, Abigail C. Phonetic correlates of primary and secondary stress in Indonesian: A preliminary study. Working Papers of the Cornell Phonetics Laboratory 11, 1-15, (1996.). 
Beckman, M. Stress and non-stress accent. Dordrecht, Netherlands: Foris Publications. (1986).

Berkovits R. "Duration and fundamental frequency in sentence-final intonation”. Journal of Phonetics, (1984);12:255-265

Boersma, P., \& Weenink, D.. Praat: Doing phonetics by computer (Version 5.3.69) [Computer software]. Retrieved from http://www.praat.org/, (2014)

Crystal, D. A dictionary of linguistics and phonetics (6th ed.). ISBN: 978-1- 405-15296-9, (2008).

De Lacy, P. The interaction of tone, sonority, and prosodic structure. In Paul de Lacy (Ed.), The Cambridge handbook of phonology. Cambridge: Cambridge University Press, ch. 12 (pp. 281-307), (2007).

Freeman FJ. "Prosody in perception, production, and pathologies". In: Yoder DE, editor. Speech, language, and hearing: Pathologies of speech and language. Vol. 2. W. B. Saunders; Philadelphia: (1982). pp. 652-672.

Fry, D. "Duration and intensity as physical correlates of linguistic stress". Journal of the Acoustical Society of America, (1955). 27, 765-8.

Fry, D. Experiments in the perception of stress. Language and Speech, 1, (1958). 120-52.

Gordon, M. (2004). A phonological and phonetic study of word-level stress in Chickasaw. International Journal of American Linguistics, (1958). 70, 1-32.

Gordon, M. Stress: Phonotactic and phonetic evidence. In M. van Ostendorp, C.J. Ewen, E. Hume, \& K. Rice (Eds.), The Blackwell Companion to Phonology . (2011). (pp. 924948). Oxford, UK: Wiley-Blackwell.

Hadding-Koch K, Studdert-Kennedy M. An experimental study of some intonation contours. Phonetica. (1964);11:175-185.

Ladd, D. R. Intonational phonology. Cambridge, UK: Cambridge University Press. . (1996).

Ladefoged, P. A course in phonetics (4th ed.). Los Angelos, CA: Harcourt College Publishers. (2001).

Lehiste I. Suprasegmentals. MIT Press; Cambridge, MA: (1970).

Lieberman P. Intonation, perception, and language. MIT Press; Cambridge, MA: (1967).

Ningsih. "Karakteristik Prosodi pada Penutur Autism Spectrum Disorder Tipe Verbal: Sebuah Pendekatan Fonetik Eksperimental". Disertasi Universitas Indonesia. (Jakarta: 2017).

Pickett, J. M. The acoustics of speech communication, fundamentals, speech perception, theory, and technology, USA. (1999).

Sluijter, A.M..C. and Van Heuven, V.J. "Supralaryngeal resonance and glottal pulse shape as correlates of stress and accent in American English", J. Acoust. Soc. Am., (1996).

Studdert-Kennedy M, Hadding K. "Auditory and linguistic processes in the perception of intonation contours". Language and Speech. (1973);16:293-313. 